\title{
Silencing of viral RNAs by small double-stranded siDNA Karin Moelling ${ }^{* 1,2}$, Jochen Heinrich ${ }^{1}$, Alexey Matskevich ${ }^{1}$, Lina Wittmer- Elzaouk $^{1}$ and Terry Kwok ${ }^{1}$
}

Address: ${ }^{1}$ University of Zurich, Switzerland, 8006 Zürich, Switzerland and ${ }^{2}$ Institute of Advanced Studies, Germany, 14193 Berlin, Germany

* Corresponding author

from Frontiers of Retrovirology: Complex retroviruses, retroelements and their hosts

Montpellier, France. 21-23 September 2009

Published: 24 September 2009

Retrovirology 2009, 6(Suppl 2):P58 doi:10.1 I86/1742-4690-6-S2-P58

This abstract is available from: http://www.retrovirology.com/content/6/S2/P58

(C) 2009 Moelling et al; licensee BioMed Central Ltd.

\section{Background}

We are developing an alternative approach to siRNA, which may be designated as siDNA, small interfering DNA, by using hairpin-loop-structured DNA oligodeoxynucleotides (ODN), targeted to viral or cellular mRNAs. ODNs activate the viral RNase $\mathrm{H}$ in retroviral particles and cellular RNases $\mathrm{H}$ inside the cell. Also Ago2 may play a role. Other inhibitory mechanisms such as translational arrest may contribute.

We selected ODNs against various viral and mRNAs of HIV [1-3], HSV [4], Influenza [5], HCV, HBV, and telomerase RNA in malignant melanoma cells in mice [6]. The ODNs were applied with or without carriers. Furthermore their effects were directly compared to those of singlestranded antisense DNAs and siRNAs to allow comparison of the various efficiencies. The ODNs were most effective in HIV. We are able to induce HIV suicide [7], inactivate HIV virus particles to prevent infections, inactivate cell-free HIV in the blood from infected individuals [8], in the vagina of mice [9], and increase survival time of retroviral-infected mice [10]. Also influenza virus replication was reduced in the lungs of a mouse model. Furthermore we could reduce malignant melanoma-formation targeting the telomerase. The effects are sequence- and dose-dependent, but the optimal algorithm is not yet known. We are analyzing whether there is a preference for $\mathrm{G}$ tracts, which may form higher-ordered structures. The dsODNs are often superior to single-stranded antisense DNA and resemble the effects of siRNAs [11] but with different kinetics. The method may complement existing silencing approaches.

\section{References}

I. Jendis J, Strack B, Moelling K: Inhibition of replication of drugresistant HIV type $I$ isolates by polypurine tract-specific oligodeoxynucleotideTFO A. AIDS Res Hum Retroviruses 1998, 14:999-1005.

2. Jendis J, Strack B, Volkmann S, Boni J, Moelling K: Inhibition of replication of fresh HIV type I patient isolates by a polypurine tract-specific self-complementary oligodeoxy-nucleotide. AIDS Res Hum Retroviruses 1996, 1 2: I I6I-1 I68.

3. Moelling K, Abels S, Jendis J, Matskevich A, Heinrich J: Silencing of HIV by hairpin-loop-structured DNA oligonucleotide. FEBS Lett 2006, 580:3545-3550.

4. Falkenhagen A, Heinrich J, Moelling K: Short hairpin-loop-structured Oligodeoxynucleotides reduce HSV-I Replication. Virol J 2009, 6:43.

5. Kwok T, Helfer H, Alam MI, Heinrich J, Pavlovic J, Moelling K: Inhibition of influenza $A$ virus replication by short double-stranded oligodeoxynucleotides. Arch Virol 2009, 154:109-I I4.

6. Noreen F, Heinrich J, Moelling K: Antitumor activity of small double-stranded oligodeoxynucleotides targeting telomerase RNA in malignant melanoma cells. Oligonucleotides 2009, 19:169-178.

7. Matskevich AA, Ziogas A, Heinrich J, Quast S, Moelling K: Short partially double-stranded oligodeoxynucleotide induces reverse transcriptase-mediated cleavage of HIV RNA and abrogates infectivity of virions. AIDS Res Hum Retroviruses 2006, 22: $1220-1230$.

8. Heinrich J, Mathur S, Matskevich AA, Moelling K: Oligonucleotidemediated retroviral RNase $H$ activation leads to reduced HIV-I titer in patient-derived plasma. AIDS 2009, 23:2I3-22I.

9. Wittmer-Elzaouk L, Jung-Shiu J, Heinrich J, Moelling K: Retroviral self-inactivation in the mouse vagina induced by short DNA. Antiviral Res 2009, 82:22-28.

10. Matzen K, Elzaouk L, Matskevich A, Nitzsche A, Heinrich J, Moelling $\mathrm{K}$ : RNase $\mathbf{H}$-induced suicide of a retrovirus by oligodeoxynucleotides in a mouse model. Nat Biotechnol 2007, 25:669-674.

II. Moelling K, Matskevich A, Jung JS: Relationship between Retroviral Replication and RNA Interference Machineries. Cold Spring Harb Symp Quant Biol 2006, 71 :365-368. 